\title{
Nuwe Testament tekste en kontekste: Oor die verband tussen hermeneutiek, identiteite en gemeenskappe ${ }^{1}$
}

\begin{abstract}
New Testament texts and contexts: On the relationship between hermeneutics, identities, and communities

This paper focuses on different texts, Pauline texts as well as those (scriptural) texts invoked by Paul in his texts, and ever-present imperial "super"-texts. The imperial co-establishes the social setting of Paul's letters given the rhetorical use of Othering in the Roman Empire with its identity politics. The rhetorical power of Paul and his scriptural texts contributed to discursive formations, since a strong sense of being and identity was negotiated through these texts, even when admitting that such formations are always in process, mutating and reformatting. Construing notions of Others was a particularly important feature in defining boundaries, for generating insiders and outsiders in Pauline texts.
\end{abstract}

\section{INLEIDING: BELANG VAN IDENTITEIT, TOE EN NOU}

Die bestudering van die Nuwe Testament gaan primêr oor hermeneutiek, die soeke na die beste moontlike interpretasie van tekste en kontekste van die antieke wêreld. Om onderrig te gee en navorsing te doen oor die Nuwe Testament in ' $n$ akademiese omgewing, veral aan 'n Teologie Fakulteit, veronderstel 'n breër hermeneutiese rol en bykomende kontekste, soos byvoorbeeld die studie van die betekenis van antieke tekste vir moderne kontekste soos geloofsgemeenskappe. Nuwe Testament tekste en kontekste is in die verlede op verskillende bruikbare en interessante maar ook ontoeganklike en laakbare wyses geïnterpreteer, in die akademie, kerk en samelewing - en dit gebeur vandag nog. Uiteraard was sakrale tekste nog altyd belangrik in hoe religieuse gemeenskappe hulleself verstaan het:'n wederkerige verhouding waar tekste gemeenskappe informeer en gemeenskappe betekenis toeken aan tekste. Die interaksie tussen teks, hermeneutiek en gemeenskappe kan daarom verduidelik word vanuit die perspektief van identiteit, waar identiteit as selfbewussyn sowel as verhouding tot "Andersheid" verstaan word. Terwyl identiteit as tema ' $n$ aanduiding van antieke belange sowel as moderne sentimente is, ${ }^{2}$ is my fokus hier op die historiese aspekte.

Die verstaan van identiteit in die Nuwe Testament in terme van ander groepe of mense as

1 'n Geredigeerde weergawe en Afrikaanse vertaling van 'n professorale intreerede gelewer op 17 April 2012, en wat met toestemming van Stellenbosch Universiteit hier gepubliseer word.

2 Die groeiende belang van identiteit in ons era het waarskynlik veel te make met die belangrike, geopolitiese gebeure in Sentraal en Noord Afrika, in die Midde-Ooste, in Oos-Europa, en die Balkan-lande, om enkele voorbeelde te noem. Daarbenewens moet verskillende militêre ekspedisies in die afgelope dekades en gepaardgaande omvorming van groot dele van die wêreld, sowel as 'n groeiende belang by (of ten minste bewussyn van) groepsidentiteit in 'n toenemend geïndividualiseerde wêreld, in ag geneem word. Vandag neem die dikwels retoriese vraag, "what is in a name?", soms nuwe betekenis aan. Belangstelling in hul herkoms, in familie-geskiedenis, oorspronge - selfs wanneer nie noodwendig itv huidige affiliasies nie - reflekteer iets van mense se besorgdheid oor identiteit sake. 
"die Ander" of deur "Andersheid" - deur "Andering" ("Othering") - het in die onlangse verlede heelwat aandag ontvang. ${ }^{3}$ Paulus se aansprake oor Andersheid of verskille tussen mense en groepe op grond van verskillende grenslyne, sluit nie die moontlikheid van substansiële verskille uit nie. Soos identiteit was Andersheid egter nie'n vaste of statiese entiteit nie. Dit was kultureel gekodeer en retories verwoord met politieke en kulturele implikasies. ${ }^{4}$ Andersheid was dikwels meer ' $n$ aanduiding van die grense wat 'n outeur wou stel as 'n beskrywing van die eienskappe van die betrokke mense. In Paulus se briewe in die Nuwe Testament is sy konstante, eksplisiete aansprake op en subtiele eggo's van die Geskrifte van Israel (min of meer die Ou Testament/ Hebreeuse Bybel) een van die beste voorbeelde van die interaksie tussen tekste, hermeneutiek en gemeenskappe, en die impak hiervan op identiteit - soos in sy appèl op Abraham in sy brief aan die Galasiërs.

Om een verdere tree te neem: die wedersyds-vormende aard van interpreterende gemeenskappe en sakrale tekste blyk teenwoordig te wees ook in geleerdes se ondersoeke. Met ander woorde, die toename in identiteit-studies (insluitende etnisiteit) gee aanleiding tot hernieude belangstelling in die aard van die raakpunte tussen tekste en kontekste. Dit is veral in die raakpunte van hermeneutiek en teks, en gemeenskappe en identiteit waar stimulus vir veel navorsingswerk in die Nuwe Testament gevind word. Die impetus volg in die voetspore van 'n lang - alhoewel nie altyd gelyke nie - tradisie van akademiese navorsing waar Bybelse tekste in hul oorspronklike antieke, Mediterreense wêreld bestudeer word.

\section{2. 'n SAAK VAN KONTEKSTE; KONTEKSTE MAAK SAAK!}

Navorsing oor identiteit-sake in die Nuwe Testament kan nie beperk word tot die noukeurige lees of literêre studie van tekste nie, omdat tekste in hul sosiale gesitueerdheid betekenis het en sáák maak. Die agtergrond, sosiale plasing of konteks ${ }^{5}$ was aan die een kant nooit afwesig in Nuwe Testament ondersoeke nie; aan die ander kant, die skopus en aard van die betrokkenheid daarvan was tipies van oneweredige aard. ${ }^{6}$ In die heel vroeë stadium van Bybel-interpretasie, toe nog grootliks beperk deur kerklike grense, het selfs die Antiocheense skool van die vierde eeu en die latere Middeleeuse quadriga reeds voorsiening gemaak vir die letterlike interpretasie van tekste. Die erkenning van die historiese geplaasdheid van tekste het meestal kwalik effek gehad op die interpretasie (Bray 1996:105-107; 147-157).

Met die aanvang van akademiese studie van die Bybel in alle erns in die negentiende eeu het die historiese bewussyn, wat Bybel-interpretasie sedert die sestiende eeu toenemend beïnvloed het, verder beslag gekry. ${ }^{7}$ Die oorheersing van die histories-kritiese metode, wat nie losstaan van die ontwikkeling van Nuwe Testament as dissipline nie, was op hande (Lategan 2004:140). Sosiohistoriese kontekste van tekste het sedert die twintigste eeu meer aandag gekry

3 Voorbeelde sluit in Buell (2005); Campbell (2008); Dunning (2009); Ehrensperger \& Tucker (2010); Hodge (2007); Wills (2008); kyk Spina (2009) oor (meestal) die OT.

4 Kategorieë van en idees oor andersheid en verskille is inherent onstabiel (kyk Dunning 2008:5) en terwyl hul gebruik in NT tekste retories is, verdien hul raakpunte met taal en politiek verdere aandag.

5 Hierdie is van die terme wat vir die sosiale plasing van NT tekste gebruik word - my voorkeur is vir "sosiale plasing" en die rasionaal daarvoor sal algaande duideliker word in hierdie artikel.

6 Vir 'n onlangse, kort verkenning van die ontwikkelings in Bybelse hermeneutiek, sien Lategan (2009a; 2009b). Thiselton (2006) verskaf 'n langer inleiding tot en bespreking van Bybelse hermeneutiek. Kyk bv ook Blount (1995), Schüssler-Fiorenza (1999) en Segovia (2000) vir verskillende oorwegings en gesprek in hierdie verband.

7 Goeie voorbeelde van waarop die radikale skuif uitgeloop het in die ontmoeting met historisiteit kan gevind word in Kümmel (1958:358-362), waar beide die outentiekheid van tekste en die geldigheid van hul aansprake onder die loep kom (kyk Lategan 2004:138). 
en 'n groter rol in Bybelinterpretasie ingeneem as ooit tevore. ${ }^{8}$ Terwyl daar tans in verskillende opsigte wegbeweeg word van die positivisties geallieerde ${ }^{9}$ histories-kritiese metode, bied nuwe historiografiese kennis ander insigte op en toegang tot geskiedenis. Die historiese geheue is immers'n dinamiese, konstruktiewe en sin-gewende onderneming. ${ }^{10}$ In samewerking met groter en konsekwente gebruik van sosiologiese, antropologiese en verwante navorsing-skemas en metodologieë onder bybelwetenskaplikes, neem historiese sake toenemend ' $n$ ander rol in Bybelinterpretasie in. ${ }^{11}$

Die andersoortigheid is tweërlei van aard, epistemologies en metodologies. Epistemologies is daar genoegsaam rede om die soektog na die "realiteit agter die teks" te laat vaar, ten dele omdat "realiteit" die verkeerde woord is vir die doel met sulke soektogte; ten dele omdat dit (daarom)'n verlore saak is, met mislukking gewaarborg; en ten dele omdat die beoogde doel met die produk (die nagejaagde realiteit) problematies is. Die argument gaan verder as die skopus van hierdie aanbieding, en daarom kan hier net volstaan word met die standpunt dat realiteit altyd gekonstrueer word; nooit an sich, objektief, of neutraal is nie; nie gevind word nie, maar altyd gekonstrueer word. ${ }^{12}$ Die tipiese intensie met histories-kritiese soektogte vir die realiteit agter die teks was (en is) geleë in 'n interpretatiewe kontroleringsfunksie, in histories-kritiese sanksionering of ten minste arbitrasie. ${ }^{13}$ Die laat twintigste-eeuse "linguistiese skuif" in Nuwe-

8 Hierdie ontwikkeling was nie onverwant aan groter epistemologiese en hermeneutiese verskuiwings in die wêreld nie. Soos Diner verduidelik in sy opstel oor die spektrum van historiese paradigmas as "delayed modes of interpretation of historical processes that have preceded them" (Diner 2007:151). Die ouderdom van die geheue oorrompel die ouderdom van die samelewing; op dieselfde wyse wat die samelewing dit met die vorige "sematicization" van die volk of die staat gedoen het, het laasgenoemde op hul beurt weer die premoderne ancient régime verplaas (Diner 2007:149-163).

9 "The theological justification, or better still, the sanctification of the historical-critical method by Käsemann, thus rests squarely on its perceived ability to guarantee closeness to (historical) reality (Wirklichkeitsnähe)" (Lategan 2004:140, beklemtoning in die oorspronklike, kyk Martin2008:3-9; Segovia 1995b:278-280).

10 "Herinnering kan beskryf word as die artikulasie van die verlede in die hede" (Pollak 2009:296). Sosiale geheue studies kom nog 'n "ordelike sentrum" kort, maar dit word gebruik in studies oor mondelinge en skriftelike mite. Sosiale geheue word verwoord deur middel van godsdiens en nasionalisme, mnemoniese praktyke in spesifieke sosiale webwerwe, die sosiale herinnering van gewone menslike aktiwiteit, of die plooibaarheid van die voorafgaande en hul politieke gebruik (Brenner en Long 2009:3-4).

11 Die weerstand van Nuwe-Testamentiese geleerdes om die singewende rol van historiese werk te erken staan in verband met teologiese redes (tekstuele geldigheid hang af van die historiese waarheid), wetenskaplike werk (erkenning van die Bybelse tekste se historisiteit, maar tog onwilligheid om die linguisties skuif volledig te verreken), en epistemologiese redes (rasionalistiese en positivistiese nalatenskap van histories-kritiese werk sowel as die ewige vrees vir anachronisme of die gevaar van "modernisering" van tekste) (Lategan 2004:145-146). Te veel geloof in die vermoë van tekste om hul eie wêreld te konstrueer of te verbeeld mag sodanige sterk agentskap toeskryf aan tekste dat dit die erkenning van die ideologiese belange van die lesers of vertalers inhibeer.

12 Opposisie teen essensialistiese denke impliseer nie die verwerping van vlees en bloed entiteite nie (soos gepropageer deur sommige vgl. Roth 2003). Dit kritiseer eerder die denkbeeldige aard van wat as vaste kategorieë (essensialisme) en seker gronde (objektiwiteit) (vgl. Brown 2001:44) voorgehou word, wanneer sosiale verskynsels in terme van transhistoriese wese onafhanklik van bewuste wesens gesien word, en die weiering om te erken dat die mense die kategoriese struktuur van die werklikheid bepaal.

13 Dikwels met teologiese regverdiging, of soos Lategan dit stel, die heiliging van die histories-kritiese metode, want dit was (is) gesien dat dit nabyheid aan die historiese werklikheid (Wirklichkeitnähe) waarborg, terwyl dit Bybel lesers beskerm teen beide 'n sacrificium intellectus wanneer die sekulêre instelling van die heilige uit die oog verdwyn, en teen 'n docetiese teologie waar Christus blote metafisiese simbool is (Lategan 2004:144, in reaksie op Ernst Käsemann se werk in die besonder). Kyk Segovia (1995:281-285). 
Testamentiese studie het helaas nie uitbuiting van tekste se sosiale plasing gestuit nie, selfs nie te midde van entoesiastiese aktiwiteit in tekstualiteit en literêre representasie nie (Lopez 2011:69). Daar is nietemin toenemende erkenning dat tekste deel is van 'n groter "inseparable, relational web of residues and artifacts that hang together in ways that are not always easily comprehensible" (Lopez 2011:80). Aangesien hierdie ontwikkelinge en skuiwe ingenestel is in verskillende magskonstellasies, is die onlangse "politiese skuif" (Stanley 2011:111) in Paulus studies nie moeilik om te verstaan nie -'n saak waarna ek binnekort terugkeer.

Metodologies is die verskil in benadering tot historisiteit ten opsigte van die sosiale plasing van die Nuwe Testament ook opvallend. ${ }^{14}$ Die verskil is geleë daarin dat weg beweeg word van "agtergrond" studies wat lig wil werp op die Andersheid van die eerste-eeuse konteks op historiese, sosiale, politieke, ekonomiese en kulturele gronde. Die fokus verskuif nou na die gebruikmaking van sosiale plasings in al hul kompleksiteit as heuristiese middels. ${ }^{15}$ Meer as om 'n byna estetiese funksie in die situering van tekste te vervul, is sosiale plasing eerder besorg oor die daarstelling van 'n geloofwaardige interpretasieraamwerk. Eerder as om waardering vir die eksotiese te ontlok, wil konteks as sosiale plasing die moontlike resonansies van die teks karteer. Die kartering sluit die waarskynlike konnotasies en denotasies van betekenis en gepaardgaande illokusionêre effekte in. Verder, eerder dat die Nuwe Testament tekste vensters open op die antieke wêreld, beaam die konstruering van geloofwaardige kontekste dat ongeïnterpreteerde realiteit nie bestaan nie (sien Lategan 2004:145).

'n Ander benadering tot geskiedenis en historiese ondersoek is dus op die tafel, en sal waarskynlik toenemend deur bybelwetenskaplikes ernstig geneem word. ${ }^{16}$ Nieteenstaande die groeiende skeptisisme teenoor historiese kritiek as metode, ${ }^{17}$ betwyfel geleerdes oor die algemeen nie die belang van 'n historiese bewussyn in die studie van die Bybel nie. Bybelwetenskaplikes toon steeds groot affiniteit vir die geskiedenis en die waarde daarvan, ${ }^{18}$ maar toenemend vir'n nuwe opvatting met betrekking tot historiografie, ${ }^{19}$ waarna sommige as

14 Die klem in die historiese kritiek op metodologiese kundigheid toon 'n aantal belangrike swakhede: die historiese klem belemmer literêre analise; die antieke wêreld is gewoonlik sonder beroep op sosiologiese en antropologiese modelle bestudeer; en die oorheersende kommer oor die teologiese inhoud en boodskap van die tekste het gelei tot 'n beperkende en idealistiese benadering tot die teks binne die vroeë Christendom, gesien byna uitsluitlik in terme van teologiese posisies, konflikte en ontwikkelings (Segovia 1995 b :281-285). Die gevare van 'n valse optimisme oor 'n self-verterende "histories-kritiese metode" is reeds duidelik in aansprake oor die metode se vanselfsprekende belangrikheid.

15 Die materiële omgewing en sosiale ligging van tekste dien nie as óf blote agtergrond óf getuienis om die historisiteit van die Bybelse tekste en figure te bewys nie (kyk Lopez 2011:79).

16 Drie belangrike aspekte van die studie van historiese narratiewe sluit in: die skryf van die geskiedenis is altyd meer en minder as die verlede; geskiedskrywing reken met die hede waartoe die verlede gelei het en is dus 'n kragtige instrument vir die legitimering van die gemeenskap, identiteitsvorming en onderrig; en, in geskiedskrywing verkry die gebeure narratiewe vorm (Green 2005:61-62).

17 Veral in teoretiese sin, aangesien histories-kritiese studies te midde van teoretiese uitdagings nog wyd beoefen word (vgl Segovia 1995a:1-32). Kyk ook Bray (1996:480-481) oor die analitiese eerder as sintetiese aard van die historiese kritiek; die gebrek aan 'n samehangende stelsel van denke; vertroue op onvoldoende data; en besorgdheid oor 'n teks se feitelike akkuraatheid. Vir die argumente oor die waarde van die historiese kritiek, hoewel soms in 'n nuwe gedaante, vgl bv Barton (1998:9-20); Collins (2004:196-198); Collins (2005); Fitzmeyer (2008).

18 "And even where [in the study of religions and theology] texts remain of central concern there is new interest in the social and cultural conditions within which they were produced and in the concrete histories of their transmission and reception" (Davaney 2001:9).

19 Historiografie is al beskryf as "the written record of what is known of human lives and societies in the past and how historians have attempted to understand them "(Partner 2008:1; beklemtoning bygevoeg) 
die Nuwe Historisme verwys ${ }^{20}$ (bv Henz-Piazza 2002). Ten spyte van die uitmergelende debat oor tekste as verhelderende vensters op die antieke wêreld of as self-reflekterende spieëls van huidige lesersbelange ${ }^{21}$ is die konstruering van geldige en geloofwaardige sosiale plasings van tekste nie 'n opsionele ekstra in Nuwe Testament hermeneutiek nie. Hoe kan dit sinvol gebeur? Wat is nodig dat die soeke na geloofwaardige historiese raamwerke nie linguistiese, strukturele en resepsie-historiese aspekte in hermeneutiek verdring nie? Hoe kan pogings om beheer oor betekenis te verkry deur aansprake op geskiedenis, vermy word? Historiografiese insigte wat die gekonstrueerde aard van realiteit ernstig neem verskuif die fokus weg van tekste wat toegang tot 'n gewaande ware realiteit bied, en ontneem kontekste hul beweerde estetiese en beheerfunksies. Die klem verskuif na'n waardering vir die gekonstrueerde ("re-membered") aard van die geskiedenis, ${ }^{22}$ met ander woorde na 'n herwaardering van die onderlinge verhouding tussen tekste en kontekste. In kort, tekste konstrueer kontekste net soveel as wat tekste ingebed is in kontekste. ${ }^{23}$

In die geval van Paulus, spreek hy op die oppervlak die saak van die Galasiër-gemeente se nuwe identiteit aan, maar op 'n dieper vlak gaan dit oor sy aanwending van 'n historiese, Joodse tradisie vir die volgelinge van Jesus in Galasië - 'n situasie tekenend van die samespel tussen hermeneutiek, tekste en gemeenskappe in historiese kontekste. Paulus se briewe met hul retoriese krag was deel van die vroegste diskursiewe en retoriese formasies van die vroeë volgelinge van Jesus, wat, soos die verskeidenheid van Nuwe Testament dokumente duidelik maak, aanleiding gegee het ook tot verskillende sosiale formasies. ${ }^{24}$ Twee aspekte van hoe Paulus te werk gegaan het met die onderhandeling van identiteit in Galasiërs was sy opname van die Geskrifte se Abraham-tradisie en Anderheid-aansprake wat by tye sterk ooreenkoms met imperiale strategieë van Andersheid toon.

\section{PAULUS, IDENTITEIT EN TEKSTE IN 'n IMPERIALE KONTEKS}

'n Herevaluering van die historiografie in teksinterpretasie moet rekening hou met die Romeinse Ryk se alomteenwoordigheid in die tyd van die Nuwe Testament, en die imperiale omgewing se invloed op tekste en hermeneutiek, gemeenskappe en identiteit. 'n Ander fokus met betrekking tot die imperiale omgewing het nie net te make met ' $n$ andersoortige benadering tot geskiedenis en sosiale ligging nie, dit is ook die gevolg van'n meer afgeronde benadering tot Paulus. Om die waarheid te sê, navorsing oor identiteit het beduidende momentum in die Nuwe Testament en Paulus studies (veral) gekry met die Nuwe Perspektief op Paulus, en meer onlangs, die Radikale Nuwe Perspektief op Paulus. Hierdie perspektiewe maak ander maniere om Paulus te verstaan

20 "New Historicism is essentially a turn away from theory and a movement in the direction of culture, history, politics, society and institutions as the social contexts of the production of texts" (Carroll 1998b:52).

21 Om die metafoor uit te brei, die teks kan bestudeer word soos portret in sy eie reg, nie vir toegang tot die verlede nie en nie as weerspieëling van die huidige leesmatige posisies en belangstellings nie (vgl Bray 1996).

22 Vanuit 'n literêre perspektief, "History is 'fictional', not in the sense of something false but in the sense of something produced in language" (Schüssler Fiorenza 1989:23).

23 Uiteraard is sulke historiografiese pogings net soseer gelaai met ideologiese belange as wat historieskritiese benaderings nog altyd was. Die ontkenning van belange is net so nutteloos soos wat die uitwissing daarvan onmoontlik is, en daarom vereis dit deursigtigheid in benadering en deurlopende kruis-wigte en teenwigte tussen die verskillende metodes en resultate.

24 Hierdie formasies "represent not the inexorable verweltlichung or development toward world-church, but the constant cycle of problematization, protest, reform. Its social power lies in what it provides in imagination and discursive formation" (Wimbush 1996:34). 
moontlik, en skram weg van die individualistiese, vergeestelikte interpretasies deur aan te dring op die belangrikheid van die sosiale ligging van Paulus en sy gemeenskappe.

Baanbrekerwerk deur Krister Stendahl (1963) en Ed P Sanders (veral 1977, kyk 1983) is verder geneem en uitgebrei deur verskeie ander geleerdes (in Paulus studies, veral JDG Dunn 1982) as die Nuwe Perspektief op Paulus (NPP). Die NPP (her)bevestig die Joodsheid van die Nuwe Testament omgewing en ontmasker in die proses invloedryke stereotipes wat die interpretasie van hierdie tekste stuur. Ondanks die grondverskuiwende werk van die NPP, is sekere talmende en dikwels negatiewe stereotipes en denke oor die Tweede Tempel Judaïsme nog nie heeltemal uitgewis nie, ook nie in teologiese gesprekke en kerklike tradisies nie. ${ }^{25}$ Meer onlangs het die huidige radikale nuwe perspektief op Paulus (Zetterholm, Nanos, Eisenbaum en ander geleerdes) die Nuwe Testament-wetenskap met nog 'n reeks vrae oor hul sosio-kulturele omgewing, en oor die identiteit van die Jode, Paulus en Jesus volgelinge in die eerste eeu gekonfronteer. In kort, deur enersyds afstand te doen van' $n$ geskiedenis van idees-benadering wat ' $n$ universele Paulus spiritualiseer en andersyds met onvergenoegdheid oor monolitiese teologiese verduidelikings wat geneig is om Jode te demoniseer, kan nuwe benaderings om Paulus se briewe sinvol te interpreteer toenemend aangewend word. Geleerdes, dikwels geïnspireer deur imperiale studies of postkoloniale benaderings, wys byvoorbeeld op die belangrikheid om Paulus binne die konteks van die Romeinse keiserryk-retoriek te lees. Alhoewel so'n leesstrategie nie sonder teenstand is nie, moet ' $n$ sekere vertroudheid met die imperiale instellings en gebruike onder die eerste-eeuse mense egter erken word, soos Deissmann (1995:341) reeds lank gelede op aangedring het.

\subsection{Imperialistiese sosiale liggings}

Veral wanneer die suidelike Romeinse provinsie van Galasië die sosiale ligging van hierdie brief is, is die imperiale konteks belangrik vir die verstaan van die Andersheid-diskoers en gepaardgaande subtiele aanduidings oor die Ander. Maar, historiese beskrywings van die materiële of ideologiese hulpbronne van die Ryk het onnodiglik gely onder'n engheid van fokus. Die Romeinse Ryk was 'n onderhandelde konsep, wat die wêreld geskep het wat dit bewoon het (vgl Hardt en Negri 2000:xv) - sonder dat die konsepsuele die sterk, geskakeerde materiële teenwoordigheid daarvan ontken. In die eerste plek was Ryk'n konstruk, 'n konsep, nie 'n nasie nie, en dus sonder grense, 'n regime wat feitlik die hele beskaafde wêreld beslaan het. Ryk se heerskappy het verder gestrek as die materiële en het sy invloed uitgeoefen nie net op die menslike liggaam nie, maar op die menslike psige ook. Onderhandelinge met en die afdwing van imperiale ideologie was nie een-dimensioneel of sonder wedersydse, kruis en dwars beïnvloeding tussen Ryk en onderdane nie. Eerder, die imperiale het afgesmeer aan mense te midde van hul weerstand daarteen (vgl Punt 2012).

'n Tema wat tot op hede verwaarloos is, ${ }^{26}$ is die doelbewuste of terloopse opstel van'n groep se identiteit teenoor imperiale invloed en impak (vgl Martin en Barnes 2003:11). Wat het dit vir sy opvatting van identiteit behels dat Paulus die retoriese en materiële wêreld van die Romeinse Ryk gedeel het? In soverre dit identiteit raak, het dit ten minste beteken dat mense in die eerste

25 Volgens Elliott gaan die NPP nie ver genoeg nie, en veral Dunn bly steeds binne die Jode / Paulus binêre kontras (Elliott 1994:55-90) en beweeg slegs vanaf'n teologiese kontras (soteriologie en die rol van geloof en werke van die wet / Torah) na 'n sosio-kulturele kontras (besnydenis, dieet wette en feesdae / Sabbat as identiteitsmerkers). Jode wat verkeerd gedink het oor hul soteriologie, word nou Jode wie se goeie soteriologie nie verhoed het dat hulle ander uitsluit op grond van hul gebrek aan Joodse lewenswyse en gebruike nie.

26 "Reimagining Paul and his communities in his Roman imperial context through the postcolonial optic of hybridity is not about Paul or his Roman imperial context. Critical reimagination is about us and our desires for particular relationships with the ancient, contemporary, and future worlds" (Lopez 2011:94). 
eeu 'n Romeins-gedefinieerde wêreld gedeel het wat blatant wantrouig was oor barbare uit die Weste en sogenaamde onstuimiges en verwyfdes uit die Ooste (Lopez 2011:81). Die Romeine se introspektiewe identiteit en hul vervreemding van ander groepe het voortgespruit uit ideologiese redes eerder as historiese "werklikheid" ${ }^{27}$ Eerste-eeuse stereotipering as spesifieke voorbeeld van Andersheid was nie die taal van eenvoudige beskrywing of akkurate profiele van ander mense nie, maar was verweef met identiteit-politiek: om die identiteit van die Self en Ander uit te stippel, en die bevordering van die eie deur die afwysing van die ander kant. ${ }^{28}$ Soos Smith (1985:47) aangevoer het, "the real urgency of a 'theory of the other'...is called forth not by the requirement to place the 'other', but rather to situate ourselves". Stereotipering het ' $n$ bevoorregte posisie in imperiale ideologie ingeneem, nie soseer (indien enigsins) om die gestereotipeerdes te beskryf nie maar het eerder die belange en identiteit van diegene wat gebruik gemaak het van stereotipering verklap met hul definiëring van die self deur ander. ${ }^{29}$

Wanneer Paulus met kwalik bedekte irritasie dan na die ontvangers van sy brief as

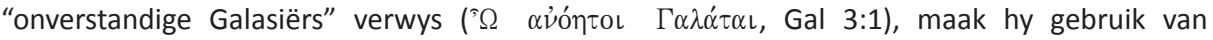
neerhalende kategorieë van die tyd. Sou die brief gerig gewees het aan 'n gemeenskap in die Romeinse provinsie van Galasië, ${ }^{30}$ sou dit ook 'n etniese verwyt ingehou het. Burgers van ' $n$ Romeinse provinsie wat aangespreek word as "Galasiërs" en boonop as "dwase" sou 'n ernstige belediging gewees het. As ' $n$ etniese belediging sou dit konnotasies ten opsigte van die berugte Keltiese volk van die Noorde ingehou het, die imperiale buitestaanders. Meer as etnisiteit was egter betrokke, omdat' $n$ aanklag van dwaasheid in daardie tyd ook'n geslagtelike belediging met afwaartse sosiale glykrag geïmpliseer het (Bassler 2007:45), Galasiër manne aan wie vroulike eienskappe nou toegeskryf word. Deur "idioties" of "dwaas" te gebruik in 'n sosiale omgewing beïnvloed deur sulke Romeinse konsepte, verwoord Paulus se opmerking sy gevoel teenoor die Galasië-gemeente in terme wat aan die identiteitspolitiek van die Romeinse Ryk herinner. Soos tekste, is ook identiteit gekonfigureer en kontekstueel geplot en maak daarom slegs sin in sosiale kontekste.

\subsection{Betrokkenheid van tekste by identiteit}

Teen die eerste-eeu het tekste in verskillende vorms'n belangrike meganisme in die formulering en afwysing (in kort, onderhandeling) van identiteit geword. Die Romeinse imperiale invloed en die versadiging van die materiële en ideologiese wêreld met tekste, skriftelik en mondeling (vgl Lopez 2008), het grootliks bygedra tot die geskrewe diskoers in die instandhouding van identiteit. ${ }^{31}$

'n Breë verstaan van tekste om sowel mondelinge as geskrewe tekste van verskillende soorte in

27 Die Romeinse Ryk het 'n spesiale dimensie verleen aan Foucault se opmerking dat "die andersheid van die ander ... per definisie niks op sigself is nie, maar alleen dit is wat ons daarop projekteer, die skatkis van ons begeertes" (Carusi 1991:102).

28 Dus, beskuldigings deur sommige Romeinse skrywers teen die vroeë Christene, soos rituele kindermoord en kannibalisme, "kan verstaan word as heeltemal geloofwaardig vir sy gehoor - nie omdat daar gedink is dat die beskuldiging 'waar' sou wees nie, maar omdat dit effektief' $n$ kollektiewe afkeer uitgespreek het vir die kenmerkende Christelike weiering om deel te neem in die gemeenskaplike kultuur van die stad en ryk" (Knust 2006:7).

29 "It is the prior understanding of the other as a dangerous threat to society that leads ancient authors, whether in history or fiction, to draw on a common stockpile of typical anti-societal actions" (Harland 2007:74).

30 In die suide van Klein-Asië, eerder as in die noordelike gebied van die subkontinent (vgl Fiensy 2004:48-50).

31 "The threefold dialogue of memory with narrative design, socio-cultural mindset and socio-political interest, in itself infused by mindsets and ideals, continues throughout the generations in ever-changing contexts, as long as memory lasts" (Pollak 2009:298). 
te sluit, is nodig, tesame met'n waardering vir die belangrike rol wat herinneringe gespeel het in die verhouding tussen tekste en identiteite. Die verhouding tussen die narratief en herinnering is sterk ${ }^{32}$ en word gekenmerk deur groot diversiteit en veranderlikheid. Die verhouding word bemiddel deur kuns en verskeie vorme van "narratief", en deur geskiedenis in narratiewe raamwerke in te pas (Pollak 2009:297). So byvoorbeeld het keiser Augustus in sy Res Gestae, waarvan die geskrewe teks versprei is oor die antieke wêreld, die geskiedenis herskryf in die naam van die Ryk. Die gebeure van die verlede is herformateer en herontwerp om só legitimiteit op te eis vir die Romeinse imperiale heerskappy en om die krag daarvan te vier. Literêre ontwerp was op komplekse wyse verweef met politieke, sosio-kulturele en godsdienstige konnotasies en kontekste.

Die maniere waarop mense in die eerste eeu ook hul eie en ander se identiteit opgerig, ontwerp en geformateer het, was veelvoudig en dikwels uiteenlopend. Kulturele, godsdienstige, (kwasi-) politieke en verskeie ander bekommernisse het telkens weer in spel gekom. Ten spyte van die hoofsaaklik mondelinge omgewing, is identiteit nogtans onderhandel ook deur die gebruik van tekste en gesaghebbende tekste in die besonder. ${ }^{33}$ Die alte dikwels steeds gangbare oorvereenvoudiging van die Nuwe-Testamentiese dokumente as "Christen" dokumente wat daarop gemik is om "die Jode" as die primêre Ander (bv Wills 2008:1, 167-193) af te wys ten einde "die heidene" te akkommodeer, is kennelik foutief. Die erkenning van hierdie fout open ' $n$ hele nuwe wêreld ten opsigte van identiteit, te midde van die gesofistikeerde maar komplekse en dubbelsinnige maniere waarop identiteit geplot was.

Paulus het die Abraham-verhaal gebruik, of beter, herwin om terselfdertyd die grense te bepaal tussen die volgelinge van Jesus en diegene buite die groep, selfs diégene wat dieselfde tradisie gedeel het, en om die in-groep te herdefinieer. In Galasiërs 4:21-5:1 het Paulus ' $n$ sekondêre verhaal van Abraham saamgeweef waarin die status van sy vroue van kardinale belang was. Slawerny word nou die maatstaf van verskil, en was bepalend vir die groepering van Jode sowel as ander wat Jesus volg aan die een kant, en alle ander Jode aan die ander kant. Die Abraham-verhaal is basies tot Paulus se Andering van nog ' $n$ groep wie se identiteit onbekend is, maar wat hom baie ontevredenheid veroorsaak het (vgl Gal 5:12; moontlik ook Gal 1:8-9): sy teenstanders. ${ }^{34}$ Met die vraag na hul eie identiteit onbeantwoord, het diegene wat Paulus geïdentifiseer het as sy teenstanders' $n$ ander opinie gehuldig ten opsigte van die kriteria en die aard van die identiteit van Jesus-volgelinge. Dit was waarskynlik die nabyheid van Paulus en sy teenstanders, en die vele ooreenkoms tussen hulle (vgl Smith 1985:46-47) wat bygedra het tot Paulus se opgewonde oorreaksie in Galasiërs, ${ }^{35}$ omdat sy eie grense só ook op die proef gestel is.

32 "...history relates to factuality and to actual situations, processes and events sequences in the past, whereas memory implies set of mind, value judgment, and, more than that, one's attitude to the past thus evoked" (Pollak 2009:296).

33 "On the one hand, then, narrative, whether in prose or in poetry, is the main channel for the performance of memory. On the other hand, the image of the past is profoundly affected by narrative. If history is a formless interplay and endless succession of occurrences, narrative imposes order and plot, and turns incidents into motifs that serve to build and to concretize the plot" (Pollak 2009:298).

34 Die ander word dikwels in situasies van konflik, wat deur'n aantal kriteria ("wette") beskryf kan word, gekonstrueer: konflik met eksterne teenstanders dien die versterking van grense; dit versterk groep strukture; konflik word aangewakker deur die nabyheid van die opponente; konflik bind teenstanders saam; en konflik dra by tot 'n unitêre beskouing van teenstanders (Wills 2004:9-10).

35 Opinies verskil oor die oorsprong en identiteit van diegene wat Paulus geïdentifiseer het as sy teenstanders in Galasië, en selfs die terminologie waarmee na hulle moet verwys word na: "Judaïseerders", "teenstanders", "aanstigters" of "moeilikheidmakers", ens. Baie terme word vir semantiese, ideologiese en historiese redes afgewys en bv Nanos verkies "beïnvloeders" (Nanos 2000:151). Daar is selfs voorgestel dat hulle gesante van Antiogië of Jerusalem was wat Paulus dopgehou 


\subsection{Konstruering / dekonstruering van identiteit in Galasiërs: Paulus as Ander?}

Paulus het die gebruik van die Geskrifte van Israel aangewend in sy strategie om binne- en buitestaanders te definieer. Sy aanwending van die Abraham-verhaal vir nie-Joodse gelowiges het voldoen aan die heersende strategie van die herwinning van tradisies van die verlede, ook van ander mense, vir die eie groep. Die funksionering van Andering in eerste-eeuse identiteit politiek vra egter om versigtigheid. In hierdie era het individualisme nie hoogty gevier nie, maar eerste-eeuse Mediterreense mense het hul identiteit, wat hul bewussyn van wees en behoort ingesluit het, afgelei van die groepe waarvan hulle hulself as deel beskou het. Die meervoud ("groepe") is insiggewend. Te midde van 'n verwarrende - vanuit ons perspektief verskeidenheid van opsies, van beskikbare affiliasies, het mense in die antieke (ook) behoort aan meer as een groep, wat bestaan het vir soortgelyke en ander doeleindes. Mense se idee van identiteit meer genuanseerd as ' $n$ eenvoudige of eensydige politieke identiteit wat in opposisie tot werklike of denkbeeldige Andere opgestel is (Wills 2008:1-5). Andersheid is nie ontken nie en is trouens by tye selfs beklemtoon, maar tog het antieke samelewings dikwels hul historiese herinneringe in terme van ' $n$ verlede wat ontleen is aan ander groepe saamgestel. As gevolg hiervan is tradisies van die verlede herwin deur gemeenskappe en groepe wat hulself met die legendes en tradisies van ander vereenselwig het (Gruen 2011:3-4). Die verhouding met die Ander was dus nie geformuleer net deur (nuwe of bestaande) kontraste tussen self en Ander nie. Andere en hul tradisies is nie net bevraagteken, verguis, of ontken nie, maar ook opgeneem en nuut "oorgedoen". ${ }^{36}$ Hierdie ambivalensie word miskien die beste gesien in self-opgenome Andersheid.

Daar is reeds in Paulus se briewe spore van die neiging tot die toeëiening van Andersheid te bespeur, $n$ tendens wat nie veel later nie in ' $n$ ontluikende Christendom prominent en selfs dominant sou word (iets wat dikwels voortgaan in ons tyd). In Galasiërs word Paulus se eie identiteit gekenmerk deur Andersheid op verskillende vlakke, of ten minste ' $n$ bewuswording van die skuif na die grens van die Andersheid. Aan die een kant het sy status as self-aangestelde apostel aan die heidene (bv. Gal 2:2,7) nie beteken dat hy afstand gedoen het van sy Joodse identiteit (Gal 2:15) nie, terwyl Paulus se missie aan die ander kant sy teenwoordigheid in vreemde gebiede geïmpliseer het. Sy nabyheid aan Andersheid het in Galasiërs sy tol van Paulus wat nou ook lyk soos 'n Ander geëis (Eisenbaum 2000:145). ${ }^{37}$ Ongeag Paulus se implisiete (bv Gal 3:6-9) en eksplisiete (Gal 4:28) aansprake op deelname aan Abraham se nalatenskap, dui die brief aan die Galasiërs op sy kommer dat hy van daardie erfenis en die gepaardgaande tradisies en identiteit uitgesluit sou kon word, en sy gepaardgaande besorgdheid om te bly binne die "Israel van God" (Gal 6:12-16).

In Filippense 3:20 maak Paulus aanspraak op hemelse burgerskap vir Jesus-volgelinge, maar reeds in die vroeër Galasiër brief het Paulus sy gehoor se fokus op die "Jerusalem daarbo" (Gal $4: 26)$ gevestig. Nie net is die Jerusalem daarbo eerder as die "huidige Jerusalem" in die brandpunt nie. Jerusalem daarbo as "moeder" is ook die verduideliking van die oorsprong van die Jesusvolgelinge en die maatstaf van hul oriëntasie. Paulus se aandrang op die hemelse Jerusalem as maatstaf van die vroeë Christelike identiteit is ingebed in sy herwinning van die Abraham-

het sedert hy Antiogië verlaat het (Wan 2007:257-258), wat die vraag laat ontstaan of hulle dieselfde groep is waarna elders verwys word, vgl Fil 3:2 (honde, doeners van die bose dade), 2 Kor 11:05, 12:11 (super-apostels); of 2 Kor 11:15 (dienaars van Satan)?

36 Dit impliseer natuurlik nie dat die gedagte van Ander onbelangrik was in identiteit-konstruksies en -onderhandelinge nie, aangesien die Ander 'n belangrike, indien nie altyd nie eksplisiete of direkte verwysingspunt gebly het.

37 Kyk ook Dunning (2008). Die opneem van 'n buitestaander identiteit in Paulus is kompleks, aangesien die andersheid wat hy verkondig vir gelowiges geleë was daarin om te verskil van hierdie wêreld, asook van sekere gebruike en tradisies (sommige waarvan hy selfs gedeel het) onder die gelowiges. 
vertellings, in soverre Abraham die paradigmatiese vreemdeling-inwoner in die Hebreeuse Bybel was (Gen 23:4). Self-andering of die aanvaarding van Andersheid in die vorm van die vreemdheid topos in teologiese diskoers was dikwels waardevol, beide vir die ondersteuning van Christene in die artikulering van 'n kontra-kulturele houding sowel as vir die bevordering van 'n gepaardgaande lewenswyse. Die aanspraak op en viering van Andersheid ${ }^{38}$ bevat egter' $n$ gevaarlike onderstroom omdat die retoriek van vreemdeling-status tot' $n$ onverrekende rigiditeit sou kon lei. ${ }^{39}$

\section{AFSLUITING}

Vrae oor identiteit(e) in Bybelse navorsing is die gevolg van verskillende belange en nie net ' $n$ weerspieëling van kontemporêre kwessies in'n vinnig veranderende wêreld vol onsekerhede nie. Identiteit, en die idee van identiteit as dinamies, betrokke, aktiwiteit-konstruerend, kompleks en verweef, het implikasies vir die sosiohistoriese en hermeneutiese kartering en die verstaan van'n aantal sentrale kwessies in Nuwe Testament navorsing. Gegewe die Bybel se impak oor baie jare heen op verskillende maniere op kulture in verskillende dele van die wêreld, en die Westerse wêreld in die besonder, kan die voortsetting van hierdie invloed op moderne konstruksies van identiteit nie geïgnoreer of geminag word nie. ${ }^{40}$ Soos geleerdes en teoretici soos Edward Said in sy Orientalism uitgewys het, het die Bybel nie agterweë gebly in die formulering van Andersheid in die Weste se kolonies nie. ${ }^{41}$ Self-opgenome Andersheid is nie sonder gevare nie: gedagtig aan die blywende retoriese waarde van die vreemdeling-topos, hoop Dunning dat hedendaagse Christene "think with greater nuance, complexity, and self-reflexivity about what they are doing when [they] make the decision ... to draw upon the topos to construct religious identity" (Dunning 2008:114). ${ }^{42}$

Daar is waarskynlik min, indien enige, versameling tekste waarmee soveel mense oor die

38 Om te verwys na die vroeë Jesus-volgelinge se waardering vir verskil deur paroikos (vreemdelinginwoner), xenos (vreemdeling of buitelander), parepidēmos (vreemdeling) en politeia (burgerskap) is merkwaardig in die lig van ander, universele eise (bv Mt 28:18-20; Hand 1:8, ens), en tegelykertyd onvoldoende omdat sulke verskil vloeibaar is en uitgepluis moet word (kyk Dunning 2009:1-3).

39 Die gevaar kom op drieledige manier na vore. Een, aansprake op vreemdeling status kan die maniere waarop Christene inderdaad die wêreld waarin hulle lewe hul eie gemaak het, belemmer. Dit kan tweedens, 'n skild word om self-kritiek te vermy, aangesien hulle identiteit op oortuigings en gedrag staatmaak wat hulle onderskei van sosiale konvensies en hul aansprake op marginale of teen-kulturele status uitbou. En, uiteindelik versterk die Ander- of vreemdeling-troop ook 'n sektariese mentaliteit wat kontak met ander gemarginaliseerde groepe kan toelaat, maar afstand teenoor meeste ander groepe in die hand werk en selfs die andersheid van al die ander groepe verplaas (Dunning 2009:113-116).

40 Instemming met die sentiment tersyde, die aanspraak dat "The Bible, directly or indirectly, defines identity for most of the people in the world" (Wills 2008:2) is dalk net te sterk - tensy die idee van indirekte invloed uitgebrei word, wat op sy beurt dan inbreuk maak op die nuttigheidswaarde van die aanspraak?

41 Miskien moet Nuwe Testamentici in Suid-Afrika hulself nie te maklik by Perkins (2009:1) skaar nie: sy kies vir die rol 'n memorialis, wat "terugkyk op 'n historiese oomblik met ooreenkomste met ons eie", eerder as 'n historikus wat in die historiografie-genre neig om "verhale te genereer wat na 'n sinvolle toekoms wys"?

42 "Handelinge van identiteitsvorming is opsigself geweldshandelinge" (Schwarz 1997:5). Ooreenkoms in terme van identiteit of eenvormigheid impliseer ook verskil, soos die konstruksie van die self altyd oproep, en, wat die Ander as buitestaanders konstrueer (vgl Lieu 2004:15). Hierdie gedagtes bereik hul swaartepunt in teoretici soos Freud, Girard en Lacan vir wie geweld en identiteitsvorming verweef is: die behoefte om 'n mens se eie identiteit te vestig behels alte dikwels die uitwissing van die identiteit van die ander. 
tydperk van soveel eeue interaksie gehad het en gebruik het in hul selfverstaan of identiteit, en ook vir die ontwerp van hulle "Ander(e)" insluitende hul vyande. By tye mag dit selfs onbewustelik gebeur het. Ook daar waar die Geskrifte hulle habitus informeer, is Bourdieu se opmerkings oor agente se betrokkenheid in meer as waarvan hulle bewus is, van toepassing: "It is because agents never know completely what they are doing that what they do has more sense than they know" (Bourdieu 1990:69). Die afgelope en voortgaande invloed van die Bybel in die vorming van moderne konstruksies van die Ander in ons land en ander dele van die wêreld, in verskeie areas van die lewe, beteken dat die studie van tekste en kontekste, van die interpretasie van gemeenskappe en geïnskribeerde herinnering van kernbelang vir beide die verstaan van die Nuwe Testament en mense se lewens vandag is. ${ }^{43}$

\section{BRONNELYS}

Barton, J. 1998. Historical-critical approaches. In The Cambridge companion to biblical interpretation, ed. J Barton, 9-20. Cambridge: Cambridge University Press.Blount, BK. 1995. Cultural Interpretation: Reorientating New Testament Criticism. Minneapolis: Fortress.

Bassler, JM. 2007. Navigating Paul. An Introduction to Key Theological Concepts. Louisville, London: Westminster John Knox.

Bourdieu, P. 1990. The Logic of Practice. Stanford: University of Stanford Press.

Bray, G. 1996. Biblical Interpretation: Past and Present. Downers Grove: InterVarsity.

Brenner, A and BO Long. 2009. Introduction: Memory, Telling and the Art of [Self-]Definition. In Performing memory in biblical narrative and beyond, eds. A Brenner and FH Pollak, 1-10. The Bible in the Modern World, vol 25; Amsterdam Studies in the Bible and Religion, vol 3. Sheffield: Sheffield Phoenix.

Brown, D. 2001. Refashioning Self and Other. Theology, Academy, and the New Ethnography. In Converging on Culture. Theologians in Dialogue with Cultural Analysis and Criticism, eds. D Brown, SG Davaney, and K Tanner, 41-55. AAR Reflection and theory in the study of religion series. Oxford, New York: Oxford University Press.

Buell, DK. 2001. Rethinking the Relevance of Race for Early Christian Self-Definition. Harvard Theological Review 94(4): 449-76.

----. 2005. Why This New Race? Ethnic Reasoning in Early Christianity. New York: Columbia University Press.

Campbell, WS. 2008. Paul and the Creation of Christian Identity. T \& T Clark Biblical Studies. London: T \& T Clark.

Carroll, RP. 1998. Poststructuralist Approaches. New Historicism and Postmodernism. In The Cambridge Companion to Biblical Interpretation, ed. J Barton, 50-66. Cambridge Companions to Religion. Cambridge: Cambridge University Press.

Carusi, A. 1991. Post, post and post. Or, where is South African literature in all this? In Past the Last Post: Theorizing Post-Colonialism and Post-Modernism, eds I Adam and H Tiffin, 95-108. New York: Harvester Wheatsheaf.

Collins, JJ. 2004. The Politics of Biblical Interpretation. In Biblical and Near Eastern Essays. Studies in Honour of Kevin J Cathcart, eds. C McCarthy and JF Healey, 195-211. London, New York: T \& T Clark International.

Collins, JJ. 2005. The Bible after Babel. Historical Criticism in a Postmodern Age. Grand Rapids: Eerdmans. Davaney, SG. 2001. Theology and the Turn to Cultural Analysis. In Converging on culture. Theologians in dialogue with Cultural Analysis and Criticism, eds. D Brown, SG Davaney and K Tanner, 3-16. AAR

43 Nuwe Testament as dissipline bestudeer Bybelse en ander kontemporêre dokumente. Hierdie tekste word bestudeer saam met en in die era of konteks waarin hulle ontstaan het, aangesien daar'n onlosmaaklike band tussen teks en konteks is. Uiteindelik gaan dit nie primêr oor die studie van tekste in kontekste in die sin van die soeke na die realiteit agter die tekste nie; maar oor die studie van tekste en kontekste in die sin van die situering van interpretasie in geloofwaardige konstruksies van die antieke wêreld - bewus daarvan die konteks gekonstrueer is en afhanklik is van interpretasie op dieselfde wyse as wat tekste van interpretasie afhanklik is. 
Reflection and theory in the study of religion series. Oxford, New York: Oxford University Press. Deissmann, GA. 1995 (1910). Light from the Ancient East: The New Testament Illustrated by Recently Discovered Texts of the Greco-Roman World. 4th ed., trans. LRM Strachan. Peabody: Hendrickson.

Diner, D. 2007. From Society to Memory: Reflections on a Paradigm Shift. In On Memory. An Interdisciplinary Approach, ed. D Mendels, 149-63. Oxford: Peter Lang.

Dunn, JDG. 1982. The New Perspective on Paul. Bulletin of John Rylands Library 65: 95-122.

Dunning, BH. 2009. Aliens and Sojourners. Self as Other in Early Christianity. Divinations: Rereading Late Ancient Religion. Philadelphia: University of Pennsylvania Press.

Ehrensperger, K and JB Tucker, eds. 2010. Reading Paul in context: Exploration in identity formation. Essays in honour of William S Campbell. Library of New Testament Studies, vol. 428. London: T\&T Clark / Continuum.

Eisenbaum, P. 2000. Paul as the New Abraham. In Paul and Politics. Ecclesia, Israel, Imperium, Interpretation. Essays in Honor of Krister Stendahl, ed. RA Horsley, 130-45. Harrisville: Trinity Press International.

Elliott, N. 1994. Liberating Paul. The Justice of God and the Politics of the Apostle. The Bible \& Liberation. Maryknoll: Orbis.

Fiensy, D. 2004. The Roman Empire and Asia Minor. In The Face of New Testament Studies. A Survey of Recent Research, eds. S McKnight and GR Osborne, 36-56. Grand Rapids: Baker Academic.

Fitzmyer, JA, sj. 2008. The Interpretation of Scripture. In Defense of the Historical-Critical Method. Mahwah: Paulist.

Green, JB. 2005. Learning Theological Interpretation from Luke. In Reading Luke. Interpretation, reflection, formation, eds. C Bartholomew, JB Green and AC Thiselton, 55-78. Scripture and Hermeneutics Series. Grand Rapids: Paternoster; Zondervan.

Gruen, ES. 2011. Rethinking the Other in Antiquity. Martin Classical Lectures. Princeton: Princeton University Press.

Hardt, M and A Negri. 2000. Empire. Cambridge, London: Harvard University Press.

Harland, PA. 2007. 'These People Are...Men Eaters': Banquets of the Anti-Associations and Perceptions of Minority Cultural Groups. In Identity and interaction in the Ancient Mediterranean. Jews, Christians and Others. Essays in honour of Stephen G Wilson, eds. ZA Crook and PA Harland, 56-75. New Testament Monographs. Sheffield: Sheffield Phoenix.

Hens-Piazza, G. 2002. The New Historicism. Guides to Biblical Scholarship: Old Testament Series. Minneapolis: Fortress.

Hodge, CJ. 2007. If Sons, Then Heirs. A Study of Kinship and Ethnicity in the Letters of Paul. Oxford, New York: Oxford University Press.

Kirk, A. 2005. Social and Cultural Memory. In Memory, tradition, and text. Uses of the past in Early Christianity, 1-24. Semeia Studies. Atlanta: SBL.

Knust, JW. 2006. Abandoned to Lust. Sexual Slander and Ancient Christianity. Gender, Theory, and Religion. New York: Columbia University Press.

Lategan, BC. 2004. History and Reality in the Interpretation of Biblical Texts. In Konstruktion von Wirklichkeit: Beiträge aus geschichtstheoretischer, philosophischer und theologischer Perspektive, eds. J Schröter and A Eddelbüttel, 135-52. Theologische Bibliothek Töpelmann, vol. 127. Berlin, New York: Walter de Gruyter.

-----. 2009a. New Testament Hermeneutics (Part I): Defining Moments in the Development of Biblical Hermeneutics. In Focusing on the Message. New Testament Hermeneutics, Exegesis and Methods, ed. A Du Toit, 13-63. Pretoria: Protea.

-----. 2009b. New Testament Hermeneutics (Part II): Mapping the Hermeneutical Process. In Focusing on the Message. New Testament Hermeneutics, Exegesis and Methods, ed. A Du Toit, 65-105. Pretoria: Protea.

Lieu, JM. 2004. Christian Identity in the Jewish and Graeco-Roman World. Oxford: Oxford University Press. Lopez, DC. 2008. Apostle to the Conquered. Reimagining Paul's Mission. Paul in Critical Contexts. Minneapolis: Fortress.

----. 2011. Visualizing Significant Otherness. Reimagining Paul(ine Studies) Through Hybrid Lenses. In The Colonized Apostle. Paul through Postcolonial Eyes. Edited by CD Stanley, 74-94. Paul in Critical Contexts. Minneapolis: Fortress. 
Martin, DB. 2008. Pedagogy of the Bible: An Analysis and Proposal. Louisville: WJK.

Martin, JM and LL Barnes. 2003. Introduction: Religion and Empire. JAAR 71(1): 3-12.

Mattingly, DJ. 2011. Imperialism, Power, and Identity: Experiencing the Roman Empire (Miriam S Balmuth Lectures in Ancient History and Archaeology). Princeton: Princeton University Press.

Nanos, M. 2000. The Inter- and Intra-Jewish Political Context of Paul's Letter to the Galatians. In Paul and Politics. Ekklesia, Israel, Imperium, Interpretation. Essays in Honor of Krister Stendahl, ed. RA Horsley, 146-59. Harrisville: Trinity Press International.

Partner, NF. 2008. Historiography (Concordia University, Wisconsin). http://www.cuw.edu/Academics/ programs/history/historiography (accessed 13 February 2008).

Perkins, J. 2009. Roman Imperial Identities in the Early Christian Era. Routledge Monographs in Classical Studies. London: Routledge.

Pollack, F. 2009. Afterword:Perspectives in Retrospect. In Performing memory in biblical narrative and beyond, eds. A Brenner and FH Pollak, 296-9. The Bible in the Modern World, vol 25; Amsterdam Studies in the Bible and Religion, vol 3. Sheffield: Sheffield Phoenix.

Punt, J. 2012. Empire and New Testament texts: Theorising the imperial, in subversion and attraction. HTS Teologiese Studies/Theological Studies 68(1), Art. \#1182, 11 pages. http://dx.doi.org/10.4102/hts. v68i1.1182

Revell, L. 2009. Roman Imperialism and Local Identities. Cambridge: Cambridge University Press.

Sanders, EP. 1977. Paul and Palestinian Judaism: A Comparison of Patterns of Religion. Philadelphia / London: Fortress Press / SCM Press.

-----. 1983. Paul, the Law, and the Jewish People. Philadelphia: Fortress Press.

Schwartz, RM. 1997. The Curse of Cain. The Violent Legacy of Monotheism. Chicago \& London: University of Chicago Press.

Schüssler Fiorenza, E. 1989. Text and Reality - Reality as Text: The Problem of a Feminist Historical and Social Reconstruction Based on Texts. Studia Theologica 43(1): 19-34.

----. 1999. Rhetoric and Ethic. The Politics of Biblical Studies. Minneapolis: Fortress.

Segovia, FF. 1995a. "And They Began to Speak in Other Tongues": Competing Modes of Discourse in Contemporary Biblical Criticism. In Reading from This Place. Vol. 1: Social Location and Biblical Interpretation in the United States, eds. FF Segovia and MA Tolbert, 1-32. Minneapolis: Fortress.

----. 1995b. The Text as Other: Towards a Hispanic American Hermeneutic. In Text \& Experience. Towards a Cultural Exegesis of the Bible, ed. D Smith-Christopher, 276-298. Biblical Seminar, vol. 35. Sheffield: Sheffield Academic Press.

----. 2000. Decolonizing Biblical Studies: A View from the Margins. Maryknoll: Orbis.

Smith, JZ. 1985. What a Difference a Difference Makes. In "To see ourselves as others see us". Christians, Jews, "others" in Late Antiquity, eds. J Neusner and ES Frerichs, 3-48. Scholars Press Studies in the Humanities. Chico: Scholars.

Spina, FA. 2005. The Faith of the Outsider. Exclusion and Inclusion in the Biblical Story. Grand Rapids: Eerdmans.

Stanley, CD. 2011. Paul the Ethnic Hybrid? Postcolonial Perspectives on Paul's Ethnic Categorizations. In The Colonized Apostle. Paul through Postcolonial Eyes, ed. CD Stanley, 110-26. Paul in Critical Contexts. Minneapolis: Fortress.

Stendahl, K. 1963. The Apostle Paul and the Introspective Conscience of the West. Harvard Theological Review 56: 199-215.

Thiselton, AC. 2006. Thiselton on Hermeneutics: Collected Works with New Essays. Grand Rapids: Eerdmans.

Wan, S. 2007. The Letter to the Galatians. In A postcolonial commentary on the New Testament writings, eds. FF Segovia and RS Sugirtharajah, 246-64. The Bible and Postcolonialism. New York: T \& T Clark.

Wills, LM. 2008. Not God's People: Insiders and Outsiders in the Biblical World. Religion in the Modern World. Lanham: Rowman \& Littlefield.

Wimbush, VL. 1996. "... Not of This World...": Early Christianities As Rhetorical Ans Social Formation. In Reimagining Christian Origins: A Colloquium Honoring Burton Mack, eds. E Castelli and H Taussig, 2336. Valley Forge: Trinity Press International.

Zetterholm, M. 2010. Jews, Christians, and Gentiles: Rethinking the Categorization Within the Early Jesus Movement. In Reading Paul in context: Exploration in identity formation. Essays in honour of William 
S Campbell, eds. K Ehrensperger and JB Tucker, 242-54. Library of New Testament Studies, vol. 428. London: T\&T Clark / Continuum.

\section{TREFWOORDE}

Hermeneutiek

Geskrifte van Israel

Identiteit

Andersheid

Paulus

Galasiërs

\section{Kontakinligting:}

Prof J Punt, Ou \& Nuwe Testament, Fakulteit Teologie, Stellenbosch Universiteit, Privaatsak X1, MATIELAND 7600. Tel 021808 2615; ePos: jpunt@sun.ac.za

Jeremy Punt (jpunt@sun.ac.za)

Stellenbosch University 